\title{
THE ULTRASTRUCTURE OF PULMONARY ALVEOLI OF THE ONE - HUMPED CAMEL (CAMELUS DROMEDARIUS)
}

\author{
Mamdouh Anwar S. El-Shammaa \\ Department of cytology and histology, Faculty of veterinary medicine \\ Cairo University
}

\begin{abstract}
The ultrastructure features of the pulmonary alveoli of the onehumped camel were basically similar to those described in other animals. The alveoli were lined by squamous type-I pneumonocytes interspersed with large irregular or cuboidal type-II pneumonocytes. They were resting on a thin basal lamina. The interalveolar septum was of variable thickness. It contained the gas exchange capillaries, fibroblasts, plasma cells and mast cells together with many collagenous and elastic fibrils. Alveolar macrophages appeared in most alveolar lumen. Intravascular active monocytes were seen.
\end{abstract}

\section{INTRODUCTION}

Among our live stock, the camel is considered as a very important animal. The camel had received little attention when compared with other species of animals. Several studies have been made on the lung in various mammalian species (Low; 1954, Epling; 1964, Atwal and Sweeny; 1971, Moussa and Heider; 1983, Moussa 1989b, Atwal, Singh, Staempfli and Minhas; 1992, Pries and kuebler; 2006 and Johnson; 2007). However, the available data regarding the lung of the camel was deficient (Moussa, 1989a). Therefore, the present work was intended to describe the fine structural features of the pulmonary alveoli of the one-humped camel (Camelus dromedarius). 


\section{MATERIALS AND METHODS}

The lungs of healthy adult two female and five male camels were collected from Cairo slaughter house of 6-8 years age after asking the owners. They were immediately cut into small pieces. For TEM examination, small blocks of lung tissue were immersed is $4 \%$ glutraldehyde solution of $0.1 \mathrm{M}$ phosphate buffer $(\mathrm{PH} 7.2)$ at $4{ }^{\circ} \mathrm{C}$. they were postfixed in $1 \%$ osmium tetraoxide solution of $0.1 \mathrm{M}$ phosphate buffer (PH 7.2) at $4^{\circ} \mathrm{C}$, dehydrated, cleared and then embedded in epoxy resin (Hayat, 1989). Thick and thin sections were cut with an ultramicrotome. Sections of 1 um thick were stained with Toluidine blue. Thin sections were stained with uranyl acetate and lead citrate and then examined by electron microscope.

\section{RESULTS}

The alveoli appeared to be lined by thin attenuated membranous pneumonocytes type-I with occasionally scattered pneumonocytes typeII epithelial cells resting on a thin basal lamina (Fig.1). The interalveolar septum was formed of connective tissue of variable thickness containing numerous blood capillaries housing different blood elements; RBCs, leukocytes and blood platelets (Fig.2). Many fibroblasts, macrophages and occasionally plasma and mast cells were encountered. In thin septum, only the basal lamina separated capillaries from the alveolar epithelium.

The type-I pneumonocytes had large, irregular nucleus which was surrounded by a thin rim of cytoplasm which extended to cover most of the alveolar surface. This surface was usually smooth but in some instances small invaginations of plasma membrane were seen especially along its basal surface (fig.3). Except for a few mitochondria and 
ribosomes, not many other organelles were in the cell. Numerous minute pinocytotic vesicles, containing an electron translucent material, were evident in some areas of the cytoplasm (Fig.4). The huge number of such vesicles may cause displacing of the epithelial memberane into the alveolar lumen. However some vesicles of large diameter were also encountered.

Type-II pneumonocytes were cuboidal or irregular cells scattered along the epithelial surface forming a continuous epithelial lining with the type-I cells. The junctional area between type-I and type-II cells had the structural characterisitics of tight junction (zonula occludens). The alveolar surface of the type-II cell was distinguished by the presence of irregular microvili. Each cell contained irregular nucleus, the cytoplasm sometimes was condensed around the nucleus to form a thick layer. The cytoplasm usually contained many mitochondria with variable sizes and shapes, a compact Golgi apparatus and rER as well as accumulations of free ribosomes and polysomes (Figs.5 \&6). Presence of large osmiophilic bodies which were specific features of type-IIpneumonocyte. These inclusions were randomly distributed within the cytoplasm but they were mostly found on one side of the cytoplasm and had no strict spatial relationship with mitochondria and other organelles. Occasionally some were in close opposition to the surface plasma membrane or even fused with it so that the contents were exposed to the alveolar space. The bodies appeared to consist of osmiophilic membranes; some of them appeared as electron dense homogenous ground that contained highly osmiophilic coarse lamellae. Large number of inclusions showed uniformly heavily osmiophitic nature while others appeared less dense and had fewer lamellae (Figs.6\&7). In some sections inclusions showed lighter osmiophilic material accumulated around heavily osmiophilic core. 
The capillaries network in the interalveolar septum was very extensive. The capillary had endothelial cells rest on a thin basal lamina. These cells were thin except in the region of their nuclei which protruded into the lumen. These nuclei appeared irregular and elongated with extensive euchromatine (Fig.2). The endothelial cytoplasm was less electrone dense than epithelial cytoplasm. Numerous pinocytotic vesicles were seen in both luminal and basal surfaces of these cells (fig.4). Perinuclear area of endothelial cell contained some organelles like mitochondria, endoplasmic reticulum and free ribosomes. Tight junctions were seen as lateral membrane thickening between adjoining endothelial cells, the intravascular features were blood plasma, RBCs, different leukocytes and blood platelets. In addition, a specific feature of camel's lung was the presence of large intravascular active monocytes. The cells were highly irregular in shape and were encountered through out the blood plasma, some of them had long cytoplasm processes. Their electron lucent cytoplasm was abundant and contained many mitochondria, rER, free ribosomes and many vacuoles. The thin side of the alveolar wall, where diffusion distances for gases are minimal, was formed by the close approximation of capillary endothelium and alveolar epithelium, the two being separated only by the fused basal lamina (Figs.2\&8)

In addition to blood capillaries the interstitial tissue of the alveolar wall contained collagen fibers with clear periodicity and elastic fibers embedded in amorphous slightly electron opaque ground substance (Fig.9). Many connective tissue cells were seen; fibroblasts were scattered among the extracellular fibers. This cell had large irregular nucleus, its cytoplasm contained mitochondria, ribosomes and well developed rough endoplasmic reticulum. Many sections, showed a contact between the fibroblasts and type-II pneomoncytes (Figs.7\& 10).

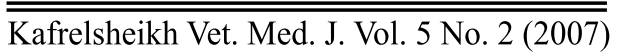


Mast cells appeared in some sections with their different morphological granules and with long surface microvilli (Fig.11). Many mitochondria and glycogen deposits were evident. Plasma cells were sparsely found in the interstitial tissue with their characteristic nucleus and Golgi zone (Fig.12). Alveolar macrophages appeared in most alveoli; they were usually seen to be close the alveolar epithelium or may be free in the lumen (Fig.13). These cells had many mitochondria and ribosomes in the form of free polysomes or as rER as well as many vacuoles.

\section{DISCUSSION}

The lung alveoli of one humped camel (Camelus dromedarius) showed nearly the same ultrastructural features as those described in other mammals. Our findings came in agreement with many authors in that the pulmonary alveoli were lined by pneumonocytes type-I and type-II alveolar epithelial cells resting on a basal lamina. Beneath this basal lamina there were capillaries and connective tissue of different thickness (Low; 1954, Karrier; 1956, Epling; 1964 Atwal and Sweeny; 1971, Rybicka, Daly, Migliore and Norman; 1974, Moussa and Heider; 1983, Moussa; 1989a, El-Nashar, Abd El Moneim and Saber; 2001 , Kelleny ; 2005 and Ibrahim , 2006).

The air alveoli, as we mentioned, were covered by membranous pneumonocytes (type-I) and granular pneumonocytes (type-II) which were joined by tight junctions. The membranous (agranular) pneumonocytes was the primary constituent of the alveolar lining; it was an endothelial like cell with attenuated cytoplasm it appeared with extending cytoplasm sheet to cover larger areas potentially available for gas exchange. Thus the susceptibility to be damaged by many inhaled Kafrelsheikh Vet. Med. J. Vol. 5 No. 2 (2007) 
agents was greater than pneumonocytes type-II (Kuhn; 1978, Kawanami, Ferrans and Crystal; 1982 and Moussa; 1989a). Weibel; (1974), Kauffman , Burri and Weibel; (1974), Vaccaro and Brody; (1981) and Kawanami et al. (1982) stated that pneumonocytes type-II replace the damaged type-I cells by a process of spreading out of their cytoplasm and disappearance of their osmiophilic lamellar bodies. This was supported by the opinion of Evans, Cabral and Stephens ,(1973) in that the pneumonocytes type-I unable to undergo mitotic division. The process of compensation of type-I cell by means of type-II pneumonocytes was supported by experiments involving epithelial repair after exposure to toxic concentration of oxygen (Kapanci, Weibel, Kaplan and Robinson; 1969 and Gould, Tosco and Wheelis; 1972). Regarding the ion transport, the general theory of ion and fluid transport in the lung was that the alveolar type-IIcells known to contain ion channels governed ion transport and that the type-I cells believed to be incapable of ion transport, (only allowed passive movement of water); in this respect recent investigators demonstrated that type-I cells were capable of ion transport and played a role in regulating lung fluid balance (Johnson, Bao, Helms, Chen, Tigue, Jain, Dobbs and Eaton, 2006 and Johnson, 2007).

In the present work, type-II pneumonocytes were of variable occurrence; the number being vary from one to several per alveolus. They present where the alveolus walls unite and form angles. They were cuboidal or rounded cells which intermittently line the alveolar surface. Their cell bodies appeared foamy and project into the alveolar lumina. Their microvilli and osmiophilic lamellar bodies were the diagnostic features of these cells at the electron microscopic level. Similar findings were described in camel (Moussa, 1989a), in buffaloes (Moussa and

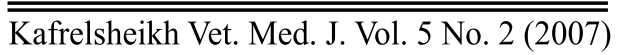


Heider, 1983 and Moussa, 1983), in lambs (Moussa, 1989b), in goat (Atwal and sweeny, 1971 and kahwa, Atwal and Purton, 1997) and in rat (El Nashar et al 2001, Kelleny, 2005 and Schmiedl, Vieten, Hühfeld and Bernhard, 2007).

In the present investigation large number of mitochondria was encountered in camel type-II pneumonocyte. Tyler and Pearse, (1965), Said, Kiein, Norell and Maddox, (1966) and Said, Harlan, Burk and Elliot (1968), have pointed out that the huge number of mitochondria reflect a high level of oxidative metabolic activity in their cytoplasm; moreover the glycolytic and the hexose monophosphate pathway enzymes may be another important source of energy and may play a role in the synthesis of pulmonary phospholipids and fatty acids. According to Hoffman (1972), Gill and Reiss(1973) and Kuhn (1978) the osmiophilic inclusions were considered as a storage form of surfactant due to their high content of phospholipids mainly dipalmitoyl phosphatidycholine; in this respect Clements and King (1976), Collet and Chevalier (1977), Meyrick and Reid (1977), Weibel and Gil (1977) and Junqueira and Carneiro (1983), demonstrated that the osmiophilic lamellar bodies contain a concenterate of the disaturated phospholipid dipalmitoyl lecithin; the same material that has been isolated from the alveolar surface lining. Banks (1981) and Schmiedle et al, (2007), reported that surfactant was a detergent - like material which reduces the alveolar surface tension and prevents alveolar collapse during expiration. Surfactant also facilitates the transport of gases between air- liquid phases in addition it has a bactericidal effect which aids in the removal of potentially dangerous bacteria that reach the alveoli (Junqueira and Carneiro; 1983 and Gehr, Im Hof, Geiser and Schürch; 2000). The last authors added that surfactant is considered as primary immune barrier. 
A contact between type-II pneumonocytes and interstitial cells, mostly fibroblasts and to some extent with mast cells, was seen in the examined sections of camel's lung; this was compatible with the results of Moussa, (1989a), Weibel, Gehr, Haies, Gil and Bachhofen, (1976) and Weinstein, Hogg, Nash and Mcnutt, (1977), They have pointed out that a fibroblastic pneumonocyte factor released by the fibroblast is necessary to enhace the differentiation and increase the production of surfactant by type-II cells

The present study revealed that, the features of the interalveolar septum of the camel were similar to those of Moussa, 1989a (in one humped camel), Moussa and Heidar, 1983 (in buffalo) and Atwal and Sweeny, 1971 (in Goat). The capillaries were arranged mostly in the centre of the interstitum; some bulge into the alveolar lumen. A close contact, between basement membrane of both endothelium of capillary and epithelium of alveolus, was apparent in some areas of the septum. Similar observations in which a thin blood gas barrier has been shown on both sides of a centrally located capillary by low $(1952,1961)$ Vaccaro and Brody (1981), Moussa (1989a) and Pries and Kuebler (2006).

This study revealed many plasma membrane invaginations and pinocytotic vesicles in both epithelial and endothelial cell, in this respect many authors have pointed out that the capillary endothelial invaginations have been identified as morphologic evidence of pinocytosis (Karnovsky ;1967, Bruns and Palade; 1968 and Rybicka et al. 1974). They may play an important role in fluid transfer across the cell (Schneeberger and Karnovsky, 1971 Gonzalez - Crussi and Boston 
1972). Dermer, (1970) and Rybicka et al, (1974) mentioned that the epithelial pinocytosis, on the other hand, may serve mainly in the removal of surfactant in its transport from the lung to the lymphatic system.

The examined camel's lung in the present study showed many connective tissue cells, specially fibroblasts, in the interalveolar wall as it was also described by Weibel et al. (1976); Kuhn, (1978) and Moussa (1989a). They mentioned that fibroblasts directly influence alveolar structure simply by their abundance. Also fibroblasts regulate gas exchange efficiency by affecting capillary diameter. Therefore the air and blood flow was regulated at the alveolar level through their contractile elements (Kapanci, Assimacopoulos, Irle, Zwahlen and Gabbiani, 1974). In agreement with Moussa (1989 $\boldsymbol{a} \& \boldsymbol{b})$ in camels and lambs respectively and Atwal and Sweeny (1971) in Goat; mast and plasma cells were sparsely present in the interstitium. Degranulation of mast cells release histamine which acts as mediator of increased capillary permeability which is associated with the adult respiratory distress syndrome (Wilson, 1974). The study revealed presence of active intravascular monocytes which appeared irregular in its outline with cytoplasmic processes. The characteristic features of these cells made us to name it macrophage-like cells. Atwal et al., (1992) demonstrated that the equine lung has pulmonary intravascular macrophages as resident phagocytes in its microvasculature. Immunocytochemistry showed more pulmonary intravascular monocytes / macrophages in rats infected with E.Coli compared with the control group (Charavaryamath, Janardhan, Caldwell and Singh, 2006). 


\section{LIST OF FIGURES}

Fig. (1): A section of lung alveoli of camel (AL) showing pneumonocytes type-I (1) and type-II (2) Toluidine blue stain, X 1025

Fig. (2): TEM of the interalveolar septum showing blood capillary housing RBCs (R), neutrophils (T), blood platelets (P), active monocytes $(\mathrm{M})$. Note endothelial nucleus $(\mathrm{N})$ with extensive euchromatine and the close approximation of capillary endothelium and alveolar epithelium (arrow). pneumonocyte type-I (1). X 5017

Fig. (3): TEM of a part of lung alveolus showing pneumonocyte type-I with its large irregular nucleus and thin rim of cytoplasm. Note its basal infoldings (I). X 15370

Fig. (4): Electron micrographs of pneumonocyte type-I epithelium (EP) and capillary endothelium (EN) Showing minute pinocytotic vesicles (arrow). (AL) alveolar lumen, (CL) capillary lumen. X 37100.

Fig. (5): Type-II pneumonocyte showing the Junctions with the adjacent cells (arrow), Note mitochondria (M), rER (R), free ribosomes (S) and vacuolated lamellar bodies (V). X 26500

Fig. (6): TEM of the lung alveolus showing pneumonocyte type-II $\left(\mathrm{P}_{2}\right)$ with its irregular nucleus $(\mathrm{N})$, different shapes of osmiophilic bodies $(\mathrm{O})$ and Golgi apparatus $(\mathrm{G})$. Note pneumonocyte type-I (P). X 15080

Fig. (7): Alveolar pneumonocyte type-II with its heavily osmiophilic bodies. Note the closely related fibroblast $(\mathrm{F})$ with clear rER cisternae (C). X 12480 
Fig. (8): Electron micrograph of alveolar septum showing the fused basal lamina (arrow) of both alveolar epithelium and capillary endothelium. Note tight junctions between endothelial cells $(\mathrm{T})$ and between alveolar epithetial cells $\left(\mathrm{T}_{1}\right)$ as well as intravascular active monocyte with its cytoplasmic processes (M). X 7690

Fig. (9): TEM of apart of the alveolar septum showing collagen fibers (C) with clear periodicity and elastic fibre (E) embedded in amorphous substance. Note pneumonocyte type-II with its osmiophilic bodies and with clear tight junction with type-I cell. X 49400

Fig. (10): Electron micrograph showing a close approximity of pneumonocyte type-II (P) and fibroblast (F). X 15370

Fig. (11): Mast cell in the interstitium of the septum with various types of granules and apical surface microvilli. (C) collagen fibers. $\mathrm{X}$ 36400

Fig. (12): A section of pulmonary alveoli with its lumen (AL) showing plasma cell $(\mathrm{P})$, macrophage $(\mathrm{M})$. Note the pneumonocyte type- II (arrow). Toluidine blue stain, $\quad$ X 1025

Fig. (13): A section of pulmonary alveoli showing alveolar macrophage (M) closely contact to alveolar epithehim as well as luminal free macrophages (LM). Toluidine blue stain, X 1025 

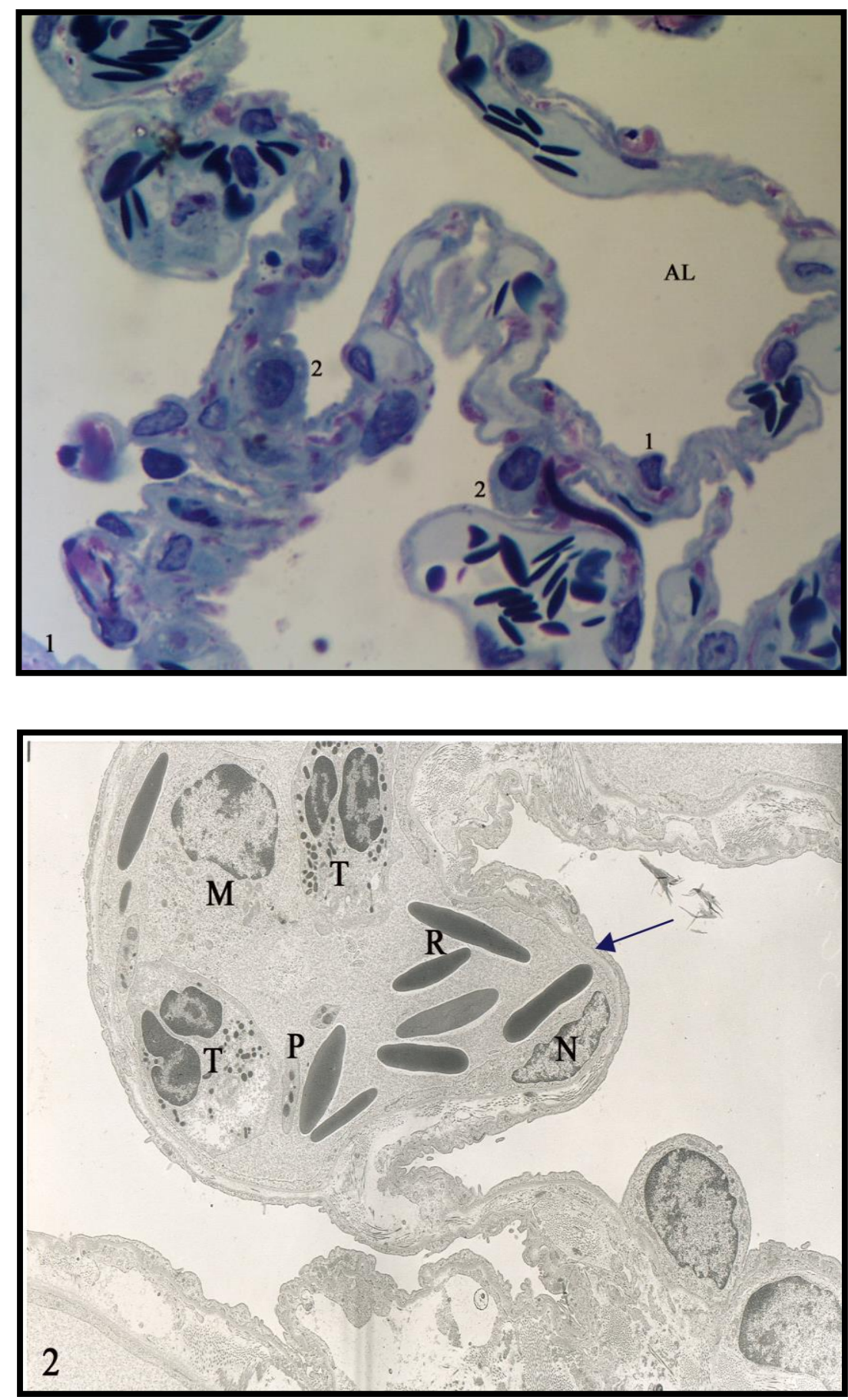

$\overline{\overline{\text { Kafrelsheikh Vet. Med. J. Vol. } 5 \text { No. } 2 \text { (2007) }}}$ 


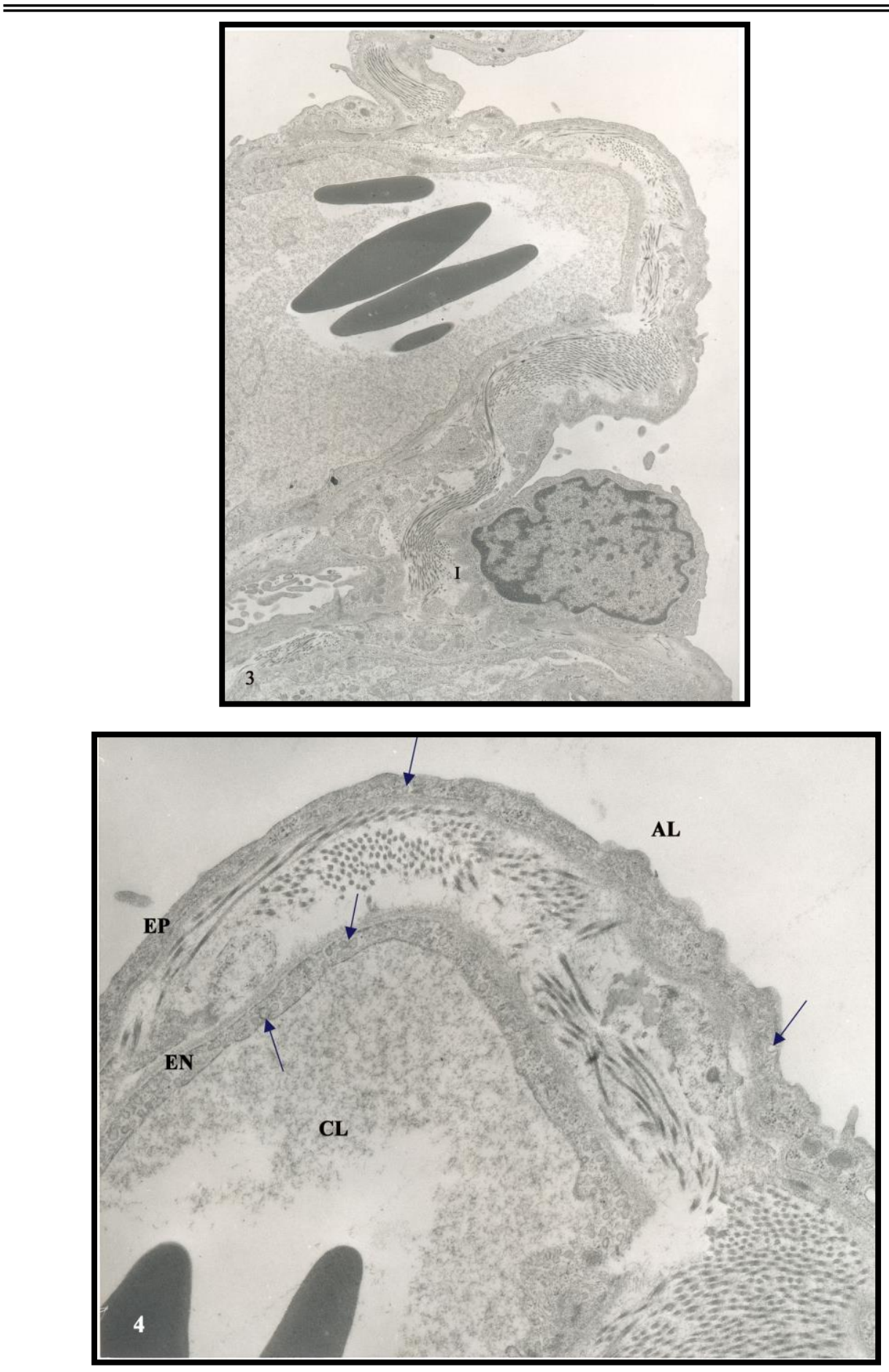

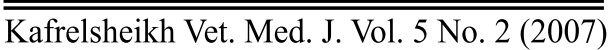



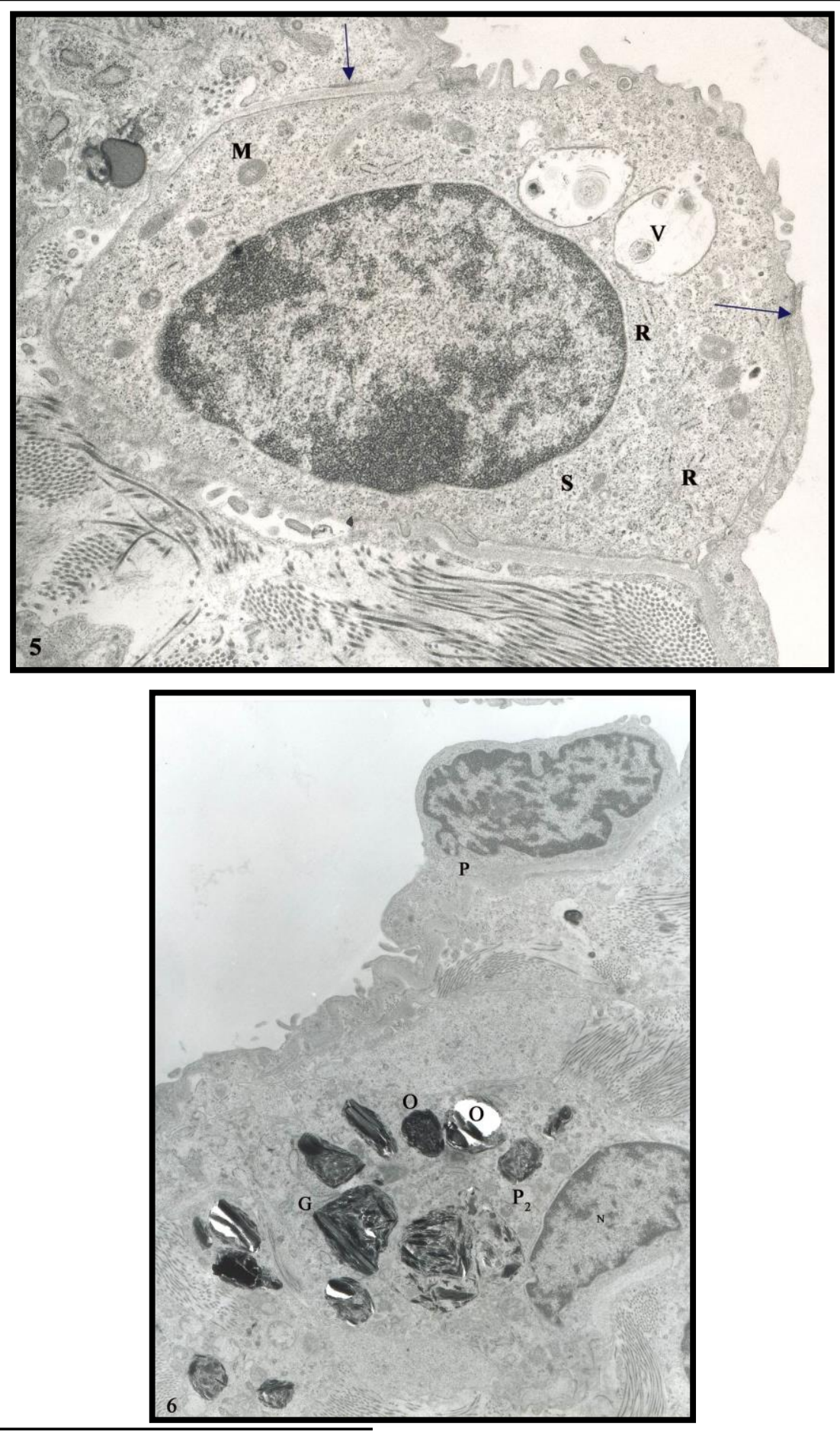

$\overline{\text { Kafrelsheikh Vet. Med. J. Vol. } 5 \text { No. } 2 \text { (2007) }}$ 

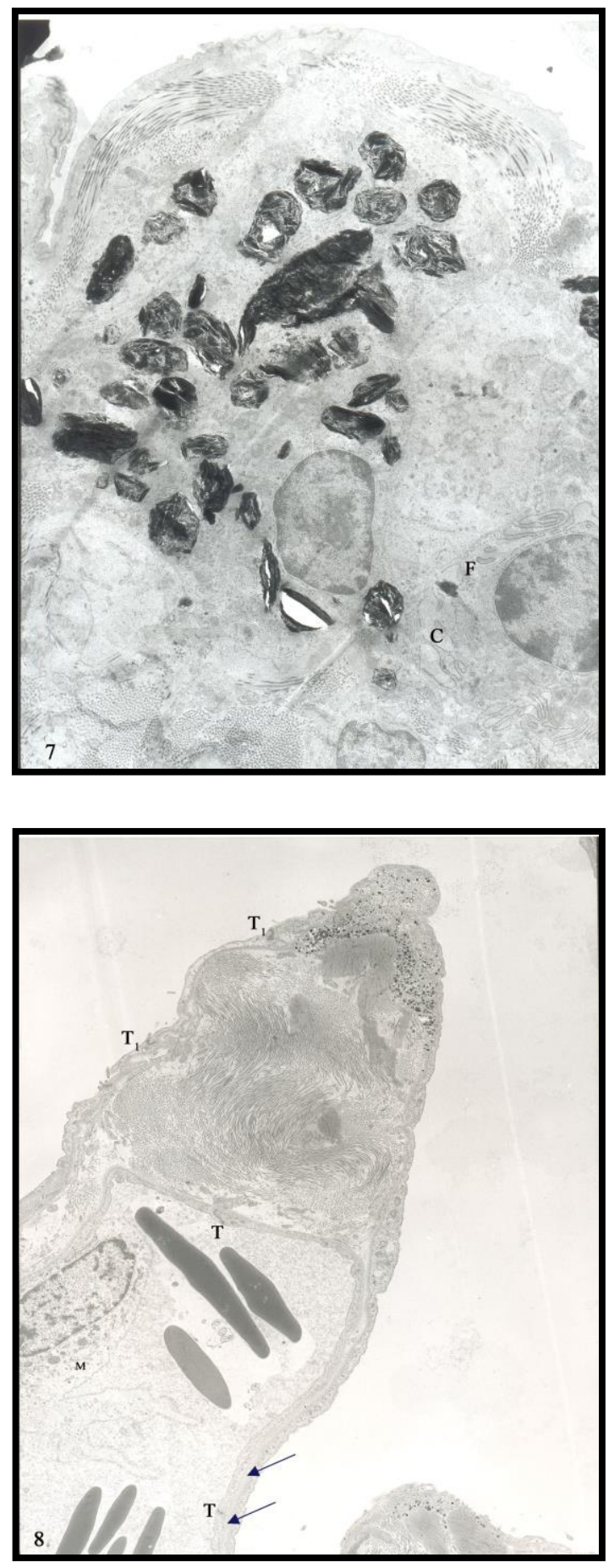

$\overline{\text { Kafrelsheikh Vet. Med. J. Vol. } 5 \text { No. } 2 \text { (2007) }}$ 

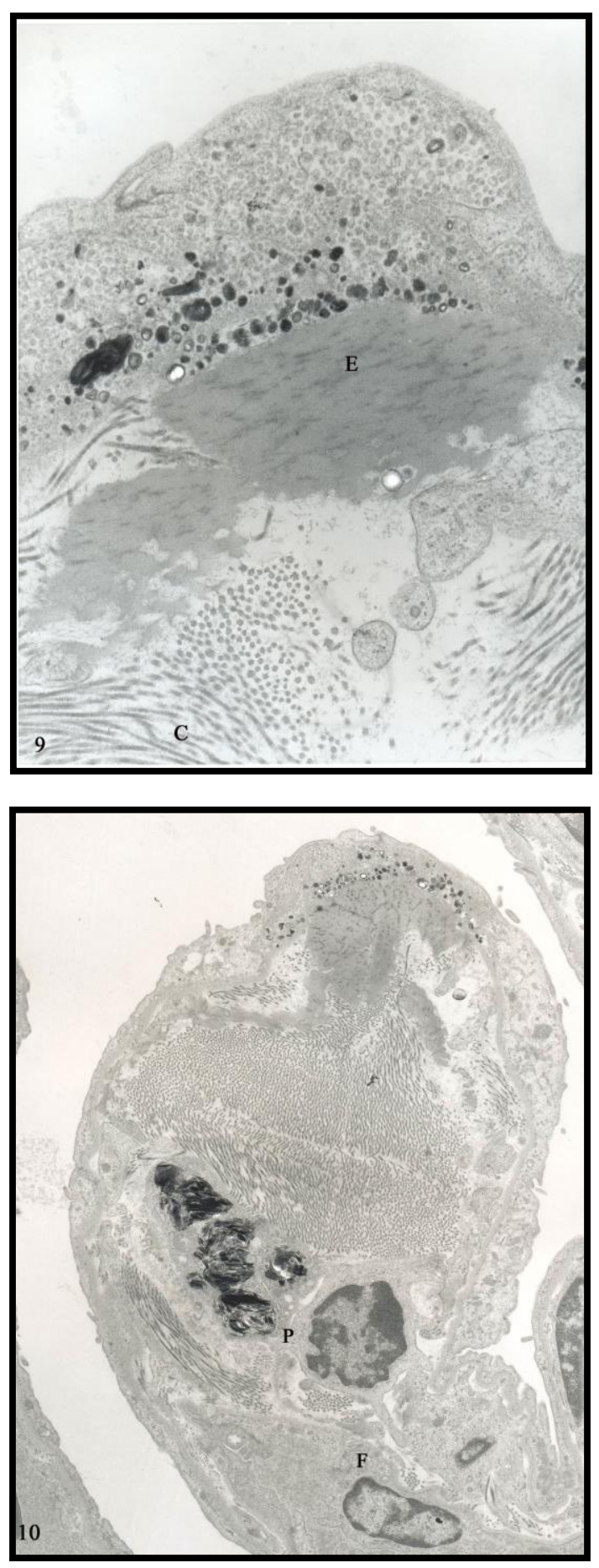

$\overline{\text { Kafrelsheikh Vet. Med. J. Vol. } 5 \text { No. } 2 \text { (2007) }}$ 

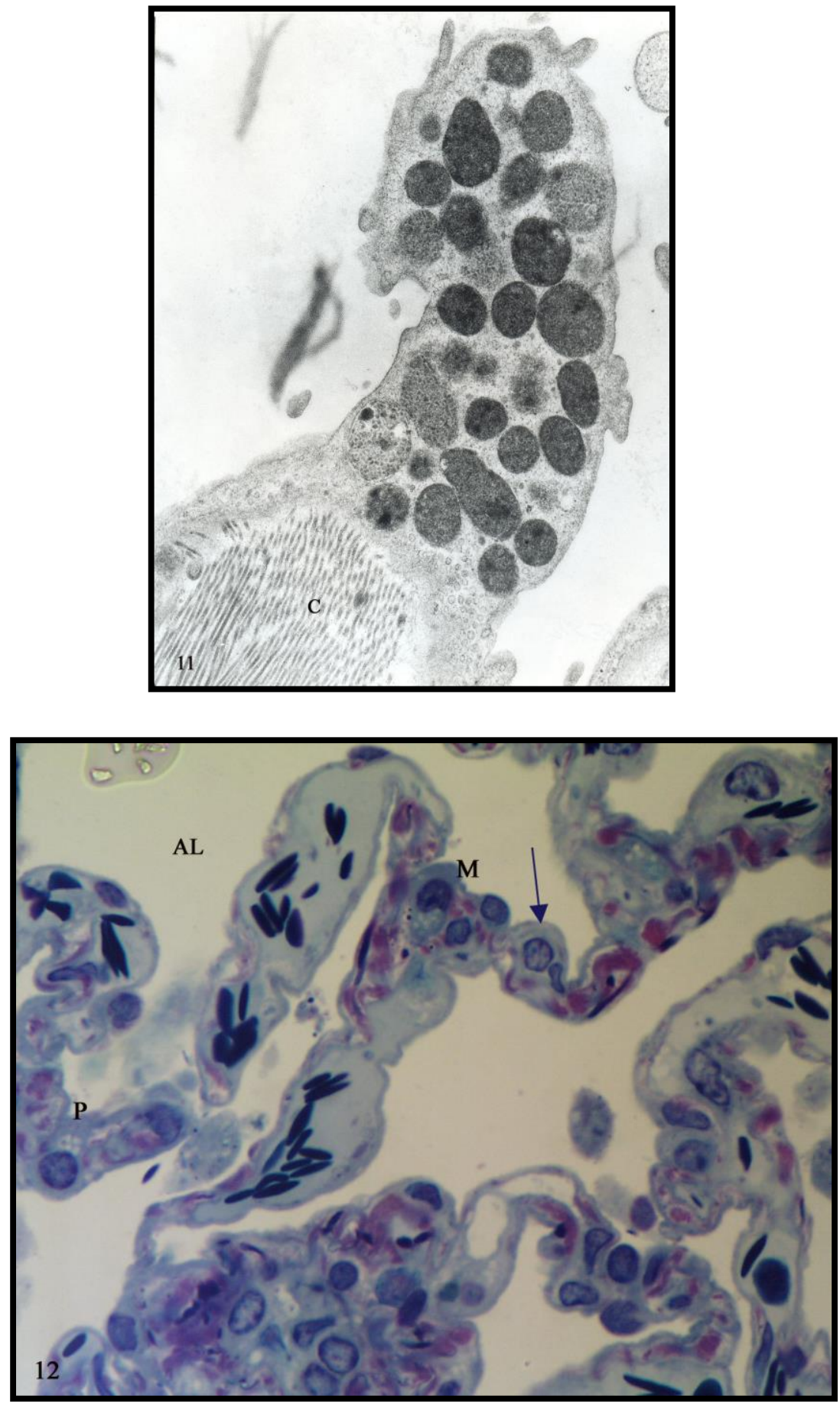

$\overline{\overline{\text { Kafrelsheikh Vet. Med. J. Vol. } 5 \text { No. } 2 \text { (2007) }}}$ 


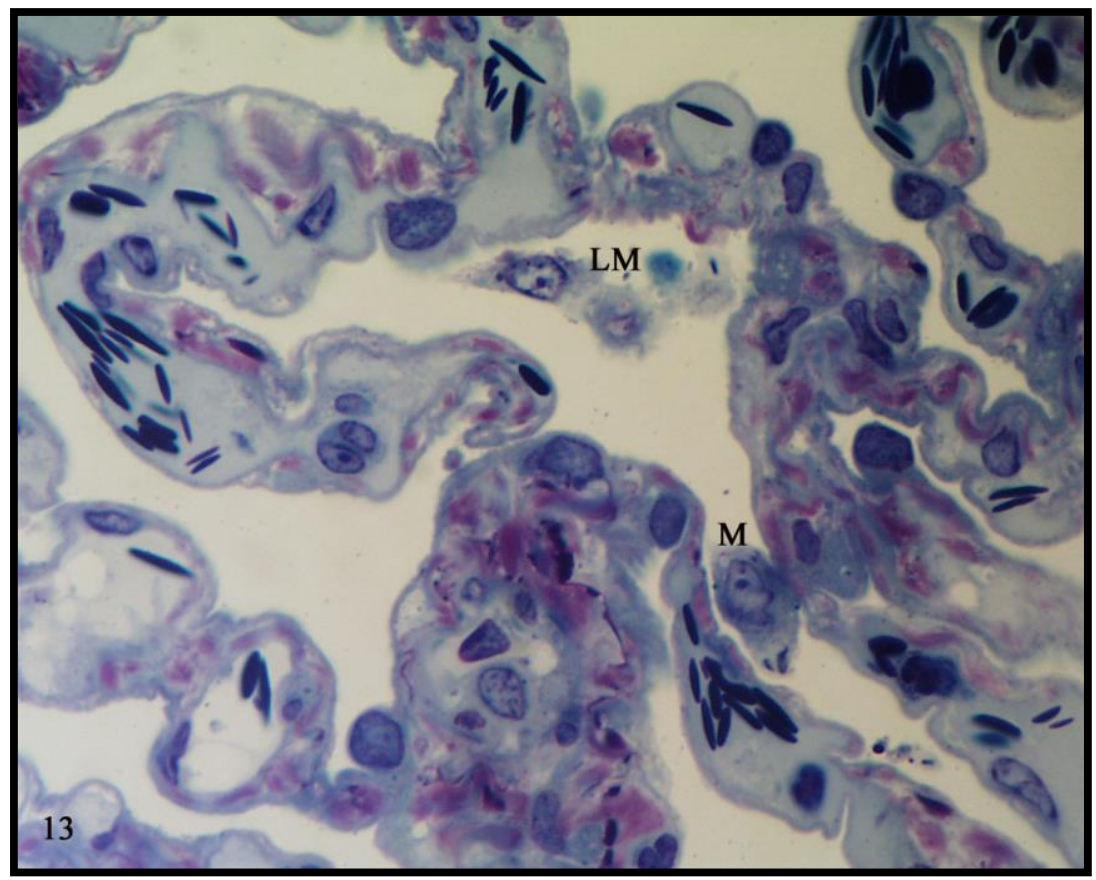

\section{REFERENCES}

- Atwal O.S.; Singh B; Staempfli H, and Minhask, K. (1992): presence of pulmonary intravascular macrophages in the equine lung: some structuro- functional properties. Anat. Rec. 234(4): $530-540$

- Atwal, O.S. and Sweeny, P.R. (1971): ultrastructure of the interalveolar septum of lung of the goat. Am. J. Vet. Res. 32 ; 1999- 2010.

- Banks, W.J. (1981): Applied Veterinary Histology. Williams $\&$ wilkins. Waverly press inc. Baltimore / London.

- Bruns, R.R. and Palade. G.E. (1968): Studies on Blood Capillaries, II, Transport of Ferritin Molecules Across the Wall 
of Capillaries J.cell Boil., 37, : 277- 299.

- Charavaryamath, C.; Janardhan, KS; Caldwell, S. and Singh, B. (2006): Pulmonary intravascular monocytes / macrophages in a rat model of sepsis. Anat. Rec. A Discov. Mol. Cell, Evol. Biol, 288(12) 1259 -1272.

- Clements, J. A. and king, R.J. (1976): composition of surface active material. Lung biology in health and disease, vol, 2, the Biochemical Basis of Pulmonary Function. Edited by R.G. Crystal. NY, Dekker, pp. 363- 387

- Collet, A. J. and Chevalier, G. (1977): Morphological aspects of type-II pneumonocytes following treatment with puromycin invivo. Am. J. Anat 148: 275- 294

- Dermer, G. B. (1970): The Fixation of Pulmonary Surfactant for Electron Microscopy. II. Transport of Surfactant Through the Air- Blood Barrier. J. Ultrastruct. Res., 31: 229 - 246.

- El-Nashar, E.M.; Abd El- Moneim, M.M. and Saber, E.A. (2001): Structural changes of lung alveoli and alveolar macrophages of the albino rat following invivo and invitro exposure to sodium fluoride. Egy. J. of Hist. Vol (24) No. 1\&2 : $97-114$.

- Epling, G. P. (1964): Electron microscopy of the bovine lung: the normal blood - air barrier. Am. J. Vet. Res. 25: 679- 689.

- Evans, M.J.; Cabral, L.J., and Stephens, R.J. (1973): Renewal of alveolar epithelium in the rat following exposure to No. Am. J. Pathol. 70: 175- 198.

- Gehr, P.; Im Hof V.; Geiser M. and Schürchs, S. (2000): the mucociliary system of the lung- role of surfactants. Schweiz and Wochenschr 130 (19): 691- 708. 
- Gil, J., and Reiss, O. K. (1973): Isolation and characterization of lamellar bodies and tubular myelin from rat lung homogenates. J. cell, biol. 58: 152- 171.

- Gonzalez- Crussi, F. and Boston, R. W. (1972): The Absorptive Function of the Neonatal Lung. Ultrastructural Study of Horseradish Peroxidase Uptake at the Onset of Ventilation Lab. Invest ., 26 : 114-121.

- Gould,V.E.; Tosco,R. and Wheelis,R.F.(1972): Oxygen pneumonitis in man. Ultrastructural observations on the development of alveolar lesions. Lab. Invest. 26: 499- 508.

- Hayat, N.A. (1989): Principales and techniques of electron microscopy, biological application $3^{\text {rd }}$ edition. Aspen publishers inc. Rockville. Maryland.

- Hoffman, L. (1972): Isolation of inclusion bodies from rabbit lung parenchyma. J. cell physiol . 79: 65- 72.

- Ibrahim, S.H. (2006): Ochratoxin A induced toxicity on alveolar walls of rat lung with evaluation of the beneficial efficacy of vitamin $\mathrm{C}$ light and electron microscopic study. The Egy. J. of Hist. Vol. (29). No. 2: 301- 314.

- Jahnson MD. (2007): Ion Transport in alveolar type I cells. Mol Biosyst. 3(3): 178- 186

- Johnson, MD; Bao, HF; Helms MN; Chen, XJ ; Tigue Z.; Jain L; Dobbs, LG. and Eaton, DC. (2006): Functional ion channels in pulmonary alveolar type I cells in lung ion transport . Proc. Natl. Acad. Sci. U.S.A. Vol . 103 (13): 4964 4969.

- Junqueira L. C. and Carneiro J. C. (1983): Basic Histology 
$4^{\text {th }}$ edition large medical publications Los Altos. California.

- Kahwa C.K.;Atwal O.S and Purton M,(1992): Transmission electron microscopy of the epithelium of distal airways and pulmonary parenchyma of the goat lung. Res. Vet. Sci. Vol. 63 (1): $49-56$.

- Kalleny, N.K. (2005): Histological study on the effect of acid aspiration on the lung of albino rat. The Egy. J. of Hist. Vol (28) No. 2: $221-240$.

- Kapanci,Y.;Assimacopoulos,A.; Irle, C.; Zwahlen, A. and Gabbiani, G. (1974): Contractile interstitial cells in pulmonary alveolar septa: a possible regulator of ventilation - perfusion ratio. Ultrastructural, immunofluorescence and invitro studies. J. Exp. Med. 136 : 630- 643.

- Kapanci, Y.; Weibel, E. R.; Kaplan, H. P. and Robinson, F. $\boldsymbol{R}$. (1969): pathogenesis and reversibility of the pulmonary lesions of oxygen toxicity in monkeys. II. Ultrastructral and morphometric studies. Lab. Invest. 20: 101- 118.

- Karnovsky, M.J. (1967): Ultrastructural Basis of Capillary Permeability Studied with Peroxidase as a Tracer. J. Cell Biol., 35: 213- 236

- Karrier, H. E. (1956): The ultrastructure of mouse lung. General architecture of capillary and alveolar walls. J. Biophysic, and Biochem . Cytol., 2 : 241 - 252.

- Kauffman, S. L.; Burri, P. H.; and Weibel, E. R. (1974): Cited by weibel, E.R. (1974):

- Kawanami, O.; Ferrans, V.J. and Crystal. R.G. (1982): Structure of alveolar epithelial cells in patients with fibrotic lung disorders. Lab. Invest. $46: 39$ - 53.

- Kuhn, C. (1978): Ultrastructure and cellular function in the 
distal lung in : " The Lung Structure, Function and Disease " Ed. By Thurlbeck, W.M. and Abell, M.R. the Williams \& Wilkins company Baltimore"

- Low, F.N. (1952): Electron microscopy of rat lung Ant. Rec. 113: 437- 449.

- Low, F.N. (1954): The electron microscopy of sectioned lung tissue after varied duration of fixation in buffered osmium tetroxide. Anat. Rec. , 120 : 827- 851.

- Low, F. N. (1961): The extracellular portion of the human blood- air barrier and its relation to tissue space. Anat. Rec. 139 : 105- 124 .

- Meyrick, B. and Reid, L.M. (1977): Ultrastructure of the alveolar lining and its development. In: The Development of the Lung. W. A. Hodson ed., M. Dekker Inc. New York, P. 123 $-186$.

- Moussa, M. H. (1983): Type - II pneumonocyte and its relation to pulmonary surfactant: An electron microscopic study. Proc. Egypt Soc. Histol. Cytol. (Dec.1983).

- Moussa, M.H. (1989a): The ultrastructure of lung of onehumped camel (Camelus dromedarius). Proc. Egypt Soc. Hist. Cytol.

(Dec. 1989).

- Moussa, M. H. (1989b): Ultrastructure of the type- II pneumonocyte in Lambs lung with special reference to the morphology of its inclusion bodies Alex. J. Vet. Sci. Vol. 5 No.1: 185- 203.

- Moussa, M.H. and Heider, El-H.A. (1983): The ultrastructure of buffalo lungs. Proc. Egypt, Soc. Hist. Cyt. (Dec. 1983). 
- Pries AR. And Kuebler WM. (2006): Normal endothelium. Handb. Exp. Pharmacol. (176 pt1) : 1- 40.

- Rybica, K.; Daly, B. D.; Migliore, J.J. and Norman, G.C. (1974): Ultrastructure of the pulmonary alveoli of the calf. Am. J. Vet. Res., 35, 213- 222.

- Said, S. I.; Harlan, W.R.; Burk, G.W. and Elliot, C. M. (1968): Surface tension, metabolic activity and lipid composition of alveolar cells in washing from normal dog lungs and after pulmonary artery ligation. J. Clin. Invest, 17: 336- 343.

- Said, S. I.; Klein, R. M. .; Norell, L. W. and Maddox, Y. T. (1966): Metabolism of alveolar cells: Histochemical evidence and relation to pulmonary surfactant. Science 152: 657- 659.

- Schmiedl A.; Vetien G.;Muhlfeld C. and Bernhard W. (2007): Distribution of intracellular and secreted surfactant during postnatal rat lung development. Pediatr pulmonol, vol 42 (6): 548- 562.

- Schneeberger, E. E., and karnovsky, M. J. (1971): The Influence of Intravascular Fluid Volume on the Permeability of Newborn and Adult Mouse Lungs to Ultrastructural Protein Tracers. J. Cell Biol.; 49: 319- 334.

- Tyler, W. S. and Pearse, A. G. (1965): Oxidative enzymes of the interalveolar septum of the rat, Thorax 20: 149- 152.

- Weibel, E.R. (1974): On pericytes; particularly their existence on lung capillaries, Microvasc, Res., 8: 218- 235.

- Weibel, E.R.; Gehr, p.; Haies, D.; Gil, j. and Bachhofen, M. (1976): the cell population of the normal Lung. In: "Lung Cells 
in Disease" edited by Bouhuys,A.P.3,Amsterdam, North Holland Publishing Co.

- Weibel, E.R. and . Gil J. (1977): Structure- function relation ships at the alveolar level. Lung Biology in Health and Disease. Vol (3) Bio- engineering Aspects of the Lung. Edited by J.B. West . New York Dekker, PP (1-81).

- Weinstein, R.S.; Hogg, J.C.; Nash, G. and McNutt, N.S. (1977): Proceeding of $1^{\text {st }}$ Annual conference on environmental toxicology, Sept, 9-11, 1970, Fairborn, Ohio, Amrl - TR- 70102, PP. 251- 273.

- Wilson, J.W. (1974): Mast cell morphologic alterations after acute pulmonary injury or respiratory distress. Chest $65: 5-7$ supplement.

- Vaccaro, C.A. and Brody, J.S. (1981): structural features of alveolar wall basement membrane in the adult rat. The J. of cell Biology Vol 91 : 427- 437.

$$
\begin{aligned}
& \text { التركيب الدقيق للاسناخ الرئوية في الجمل وحيد السنام (الجمل الاروميديري) } \\
& \text { د./مدوح أنور سالم الشعاع }
\end{aligned}
$$

قسم الخلية والأنسجة - كلية الطب البيطري - جامعة القاهرة

تتتابه صفات التركيب الدقيق للاسناخ الرئويه في الجمل وحيد السنام مع التركيب الدقيق الموصوف في الحيوانات الأخرى حيث تتكون الخلايا المبطنة للاسناخ من نوعين من الخلايا: النوع 
الأول هو الخلايا السنخية الحرشفية البسيطة (خلايا الرئة - I ) و هي خلايا مسطحة للغاية ذات نواه

غير منتظمة والسيتوبلازم خارج منطقة النواه يكون رقيق جدا. والنوع الثاني من الخلايا هو عبارة عن خلايا مكعبة سنخية (خلايا الرئة - II)، وهي خلايا تتميز باحتوائها علي اجسام صغيرة محبة لحمض الازميك وتحمل علي سطحها خملات دقيقة. وللاسناخ غشاء قاعدي رقيق مشترك مع الغشاء القاعدي للشعيرات الدموية الموجودة في النسيج البيني بين الاسناخ أو بالقرب منه. يتميز هذا النسيج البيني باحتوائه علي ألياف غروية ومرنة بالإضافة إلي وجود خلايا ليفية، خلايا بلازمية وبلاعم. هذا وقد لوحظ وجود بعض البلاعم الطليقة في تجاويف معظم الاسناخ الرئوية. 